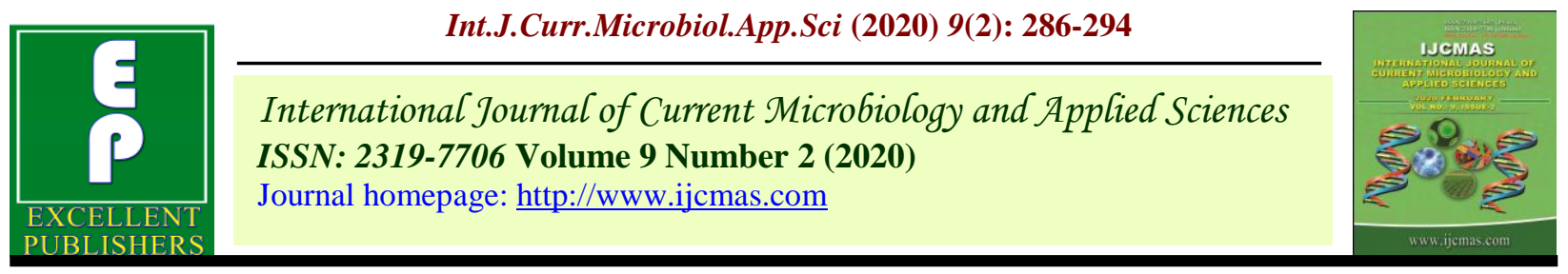

Original Research Article

https://doi.org/10.20546/ijcmas.2020.902.036

\title{
Interaction of Different Carbon Related Microbial Activities as Influenced by Green Manure and Bio inoculants in Kharif Maize Crop
}

\author{
Jaspreet Kaur $^{1 *}$ S. K. Gosal ${ }^{1}$, S. S. Walia ${ }^{2}$, Jupinder Kaur ${ }^{1}$ and Neha Khipla ${ }^{1}$ \\ ${ }^{1}$ Department of Microbiology, Punjab Agricultural University, Ludhiana-141 004, India \\ ${ }^{2}$ School of Organic Farming, Punjab Agricultural University, Ludhiana-141 004, India, India \\ *Corresponding author
}

\section{Keywords}

Bioinoculant,F/B

Biomass Ratio,

Green Manure,

Kharif Maize,

Microbial

Communities, Soil

Enzymes

Article Info

Accepted:

05 January 2020

Available Online:

10 February 2020

A B S T R A C T

Study was conducted to evaluate the effect of different fertilizer regimes on fungal to bacterial ratio and correlation between the carbon related microbial community and enzyme activities. Result showed that application of bioinoculant with green manure significantly decreased F/B biomass ratio (0.441) which is significantly lower than treatment having sole application of inorganic fertilizer. Application of green manure and bioinoculant has significant positive effect on population of cellulose utilizing bacteria and amylolytic bacteria indicated by significant positive correlation of these microbial groups with enzyme activities. Correlation analysis revealed that amylolytic bacteria were dominant C-related microbial group as they showed significant positive correlation with all microbial communities and enzymatic activities irrespective of fertilizer applications. However, treatment T4 having application of green manure and bioinoculant significantly enhanced the correlation coefficient of amylolytic bacteria with amylase activity. Invertase activity was positively correlated with all enzyme activities in treatment having either single or combined application of green manure and bioinoculant. High significant positive correlation ( $\mathrm{r}=0.874 @ \mathrm{p}=0.01)$ was recorded in treatment having bioinoculant application indicated positive impact of bioinoculant on organic matter decomposition in soil. So, it can be concluded that combined application of green manure and bioinoculant directly influenced relative number of bacterial population and interrelationship between enzymatic activities in kharifrhizospheric soil.

\section{Introduction}

Now days, degradation of agricultural soils is of great concern for agricultural biologists. Intensive utilization of chemical fertilizers, soil erosion, nutrient leaching, runoff, organic matter mineralization and unsubstituted crop removal (Balota and Chaves 2010) are major causes of soil degradation. Cultivation of different species in same field can be an alternative approach to enhance microbial diversity and soil sustainability. Application of plant legume crops as green manure can serve this purpose. As, Legume crops have higher biomass production per unit area, high nutrient content, enhance nutrient mobilization, can biological fix nitrogen, robust and have deep rooted system. These 
properties make the green manure ideal for ensuring soil surface protection as well as nutrient mobilisation

Different plant species varies in quantity and quality of carbon and nitrogen content in soil which affects their fate in soil environment, thus directly affect soil organic matter decomposition and nutrient turnover. Plant characteristics determine the mineralisation and immobilization during its decomposition in soil.

Organic matter decomposition in soil is mediated by catalytic action of microbial enzymes secreted in rhizospheric soil (Dick 1994). Microbial enzymes were continuously produced and accumulated in soils thus affect recycling of nutrients (Tabatabai 1994; Dick 1997).

Enzymatic activity is likely to be the potential index which can fully reflect the changes of the soil biology, productive forces and its quality (Zhang and Liang 2001). Soil microorganisms together with soil enzymes promote the nutrient transformation and organic mattercycling that maintains normal soil metabolic functions.

So, soil enzyme can be used as a unique integrative biological indicator of the intensity of certain biochemical processes due to their close relationship with soil biology and the rapid response to changes in soil management (Dick 1994, 1997; Bandickand Dick 1999). The potential benefits in soil quality and crop production with change in fertilization regimesof soil is necessary for better insight into microbial diversity and activity.

The objective of this study was to evaluate carbon related soil microbial communities and enzymaticactivities in relation to green manure and bioinoculant application in kharif maize.

\section{Materials and Methods}

\section{Location and weather}

A field experiment was conducted consequently for two years (kharif 2016 and 2017) at School of Organic Farming of the Punjab Agricultural University, Punjab, India. This location was situated at an elevation of $292 \mathrm{~m}$ above mean sea level and lie at $\mathrm{N}$ $30^{\circ} 54.570^{\prime}$ latitude and E $75^{\circ} 46.732^{\prime}$ longitude under the Trans-Gangetic Plains' agro-climatic zone.

The meteorological data showed that weekly mean maximum air temperature during experimental period ranged between 32.2 to 41.1 and 32.0 to 38.9 in year 2016 and 2017 respectively, while the weekly mean minimum temperature ranged between 24.7 to 29.2 and 21.0 to 30.6 during year 2016 and 2017 respectively. A total of $496.7 \mathrm{~mm}$ and $396.3 \mathrm{~mm}$ rainfall received in kharifseason of 2016 and 2017, respectively.

The maximum value of mean weekly rainfall was $152.4 \mathrm{~mm}$ (in 2016) and $100 \mathrm{~mm}$ (in 2017) received during $26^{\text {th }}$ and $35^{\text {th }}$ SMW, respectively. The mean weekly relative humidity ranged between $42-79.5 \%$ and $42-$ $79 \%$ during 2016 and 2017, respectively.

\section{Experimental details}

The experiment was laid out in a random block design with three replications. Sunn hemp (Crotolariajuncea) was used as green manure crop in the experiment. Nitrogen (110 $\mathrm{kg} /$ acre urea) was applied in three split doses whereas the full dose of phosphorus (di ammonium phosphate $55 \mathrm{~kg} / \mathrm{acre}$ ) and potassium (muriate of potash $20 \mathrm{~kg} / \mathrm{acre}$ ) were applied at sowing of maize crop (var. PMH1). In situ incorporation of Crotolariajuncea (Sunn hemp) was done eight days before the sowing of maize crop 
(in green manured plots). The bioinoculant used in the experiment was bacterial consortium which has dual ability to degrade cellulose as well as has plant growth promoting activities.

This bio-inoculant was sprayed over green manure just before the ploughing; application of this bio-inoculant reduced the fallow period between maize sowing to 8 days which was usually 14 days. The maize crop (variety - PMH1) was raised by following the crop management practices recommended in Package of Practices, PAU, Ludhiana. A total of 4 different combinations of inorganic fertilizer, organic amendment (with and without green manure) and bio-inoculant (with and without bio-inoculant) were made which are listed in table 1.

\section{Soil sampling and analysis}

Soil samples were collected from different treatments during 2016 and 2017 kharifcropping season. Soil subjected to different managements was sampled at four different time intervals $(0,30,60$ days after sowing and at harvest) over the maize growth period and was analysed for different characters using standard protocols. Plants were uprooted from five random locations from each treatment. Loose soil was shaken off the roots and the soil that adhered strongly to the roots was carefully brushed from the roots and kept as rhizospheric soil. The five rhizospheric samples from each treatment were combined to form one representative sample and analysed.

Table.1 Different combinations of treatments used in the experiment

\section{Treatments}

\begin{tabular}{l|l} 
T1 $100 \%$ rec. $N$
\end{tabular}

T2 Bio-inoculant $+\mathbf{1 0 0 \%} \mathbf{N}$

T3 Green manure $+\mathbf{1 0 0 \%} \mathrm{N}$

T4 Bio-inoculant + Green manure $+\mathbf{1 0 0 \%} \mathbf{N}$

Table.2 Fungal to bacterial biomass ratio in rhizospheric soil of kharif maize (var. PMH1)

\begin{tabular}{|c|c|c|c|c|}
\hline & 30DAS & 60 DAS & 90 DAS & Mean \\
\hline T1 & $0.442^{\mathrm{aB}}$ & $0.439^{\mathrm{aB}}$ & $0.499^{\mathrm{aA}}$ & 0.460 \\
\hline T2 & $0.430^{\mathrm{bB}}$ & $0.432^{\mathrm{aB}}$ & $0.484^{\mathrm{aA}}$ & 0.449 \\
\hline T3 & $0.445^{\mathrm{aB}}$ & $0.439^{\mathrm{aC}}$ & $0.488^{\mathrm{aA}}$ & 0.457 \\
\hline T4 & $0.428^{\mathrm{bB}}$ & $0.422^{\mathrm{bB}}$ & $0.472^{\mathrm{bA}}$ & 0.441 \\
\hline
\end{tabular}

*Values are pool mean of data collected during two kharif maize seasons 
Table.3 Correlation analysis of carbon related bacterial communities and enzymatic activities in rhizospheric soil of kharifmaize var. PMH1.

\begin{tabular}{|c|c|c|c|c|c|}
\hline \multicolumn{6}{|c|}{ A) Treatment $\mathrm{T1}$} \\
\hline & CUB & $\begin{array}{c}\text { Amylolytic } \\
\text { bacteria }\end{array}$ & Amylase & Invertase & Cellulase \\
\hline CUB & 1 & & & & \\
\hline $\begin{array}{r}\text { Amylolytic } \\
\text { bacteria }\end{array}$ & $.899^{* *}$ & & & & \\
\hline Amylase & $.832^{* *}$ & $887^{* *}$ & 1 & & \\
\hline Invertase & .059 & .449 & .390 & & \\
\hline Cellulase & $.871^{* *}$ & $.760^{*}$ & $.916^{* *}$ & -.007 & 1 \\
\hline \multicolumn{6}{|c|}{ B) Treatment $T 2$} \\
\hline & CUB & $\begin{array}{r}\text { Amylolytic } \\
\text { bacteria }\end{array}$ & Amylase & Invertase & Cellulase \\
\hline CUB & 1 & & & & \\
\hline $\begin{array}{r}\text { Amylolytic } \\
\text { bacteria }\end{array}$ & 443 & & & & \\
\hline Amylase & $.713^{*}$ & $.761^{*}$ & 1 & & \\
\hline Invertase & .519 & $839^{* *}$ & $.943^{* *}$ & & \\
\hline Cellulase & $.874^{* *}$ & .304 & $.776^{*}$ & .539 & 1 \\
\hline \multicolumn{6}{|c|}{ C) Treatment $\mathrm{T3}$} \\
\hline & CUB & $\begin{array}{c}\text { Amylolytic } \\
\text { bacteria }\end{array}$ & Amylase & Invertase & Cellulase \\
\hline CUB & 1 & & & & \\
\hline $\begin{array}{r}\text { Amylolytic } \\
\text { bacteria }\end{array}$ & $.813^{* *}$ & & & & \\
\hline Amylase & $.774^{*}$ & $.876^{* *}$ & 1 & & \\
\hline Invertase & $.701^{*}$ & $.899^{* * *}$ & $.983^{* * *}$ & & \\
\hline Cellulase & $.850^{* *}$ & $.760^{*}$ & $.930^{* *}$ & $.859^{* *}$ & 1 \\
\hline \multicolumn{6}{|c|}{ D) Treatment T4 } \\
\hline & CUB & $\begin{array}{l}\text { Amylolytic } \\
\text { bacteria }\end{array}$ & Amylase & Invertase & Cellulase \\
\hline CUB & 1 & & & & \\
\hline $\begin{array}{r}\text { Amylolytic } \\
\text { bacteria }\end{array}$ & $.916^{* *}$ & 1 & & & \\
\hline Amylase & $.767^{*}$ & $.900^{* *}$ & 1 & & \\
\hline Invertase & $.828^{* *}$ & $.895^{* *}$ & $.985^{* *}$ & 1 & \\
\hline Cellulase & $.828^{* *}$ & $.841^{* *}$ & $.938^{* *}$ & $.977^{* *}$ & 1 \\
\hline
\end{tabular}

*. Correlation is significant at the 0.05 level (2-tailed). **.Correlation is significant at the 0.01 level (2-tailed). \#values are pool mean of data collected during two kharifmaize seasons 
Soil samples were analysed for population of various microbiological communities associated with carbon cycling such as amylolytic bacteria and cellulose utilizing bacteria using serial dilution spread plate method. Fungal and bacterial population were enumerated to calculate fungal to bacterial biomass ratio (Olsen and Bakken 1987).

Soil samples were air-dried under shade, pounded to break up large clods, sieved $(<2$ $\mathrm{mm}$ ), and analysed for soil biological properties as amylase activity, invertase activity and cellulase activity as per the methodology of Cole (1977) and Tu (1982) and Deng and Tabatabai (1994), respectively.

\section{Statistical analysis}

The mean values recorded for different parameters and results were subjected to Pearson's correlation analysis to access inter relationship between the biological parameters as affected with different treatments irrespective of time intervals using SPSS 16.0 software.

\section{Results and Discussion}

\section{Effect on fungal and bacterial biomass ratio}

Fungal to bacterial biomass ratio is widely used metric to access the environmental impact on functionality of soil microbial communities (Strickland and Rousk 2010).

Agricultural management practices have strong effect on relative proportion of fungi and bacterial population in soil; which can act as a good indicator of any alternation in soil environment.

In present study, treatment having green manure application (T3) resulted in lower $\mathrm{f} / \mathrm{b}$ biomass ratio (0.447) in soil as compared to inorganically maintained fields (0.460). However, application of bioinoculant along with green manure showed additive impact in decreasing $\mathrm{F} / \mathrm{B}$ biomass ratio (0.441) which is significantly lower than treatment having sole application of inorganic fertilizer (T1).

That might be due to application of 1) green manure that increased relative availability in nitrogen content in soil, 2) enhanced decomposition with application of bioinoculant on green manure. So, integrated application ofgreen manure and bioinoculant leads to bacterial dominance in rhizospheric soil of maize crop.

During the growth of maize crop, significantly higher $\mathrm{F} / \mathrm{B}$ biomass ratio was recorded at harvest of crop, which might be due to low availability of nutrients at crop harvest. The present results were supported by De Vrieset al.(2006) that application of higher nitrogen fertilizer significantly decreased the $\mathrm{F} / \mathrm{B}$ biomass ratio in soil.

They also concluded that organic matter with low $\mathrm{C} / \mathrm{N}$ ratio $(<20$, such as green manure) increased the bacterial dominance in soil whereas high $\mathrm{C} / \mathrm{N}$ ratio organic matter $(>20)$ significantly enhanced $\mathrm{F} / \mathrm{B}$ biomass ratio in soil. Strickland and Rousk (2010) reported that plant residue application favoured the bacterial population due to their high substrate contact ability owing to their smaller size.

Green manure crops have low $\mathrm{C} / \mathrm{N}$ ratio, which is ideal for the consumption by bacteria (low $\mathrm{C} / \mathrm{N}$ ) as they required nitrogen rich substrate to feed. The results were consistent with Malik et al.(2016) that application of fertilizers (organic and inorganic) in soil favours the bacterial community whereas a substrate with a relatively wide $\mathrm{C}: \mathrm{N}$ ratio enhances growth of the fungal population. 
Inter-relationship between carbon related microbial communities and soil enzymes

Soil enzyme activities are of paramount importance to evaluate functions of microorganisms, cycling of nutrients and organic matter decomposition. Agronomic practices have immense effect on the correlation between the microbial community density and functionality. In present study, application of green manure and bioinoculants significantly affect the relationship between carbon related microbial communities andtheir associated enzyme activities.

Amylase is very important soil enzyme that catalyzes $\beta$-glycosidic bond of starch and releases glucose in surrounding medium. In our study, amylase activity showed a strong positive correlation with amylolytic bacterial population in all treatments. However, application of green manure in treatment T3 significantly enhanced their correlation coefficient r=0.876 @ 0.01 level of significance as compared to other treatments (Table 3).

The application of bioinoculant further enhanced correlation coefficient ( $\mathrm{r}=0.900$ @ 0.01 level of significance) between amylase enzyme and amylolytic bacteriathat might be due to inherent capacity of microbial inoculant to solubilize starch. The strong positive correlation of amylolytic bacteria with all other biological parameters irrespective of the fertilizer regimes indicated that they were prominent microbial group in maize rhizosphere.

Results of present study corroborated with the results reported by Myoekowet al. (1996) and Perucciet al.(1997) that use of organic fertilizers resulted in the increase of organic carbon content in soils and introduced enormous amount of organic substance into soil that enriches the microflora of a given soil in terms of quantity and quality. The study was consistent with Boruta and Paluszat (2006) that organic fertilization favoured the development of starch decomposing microorganisms, which testifies an increased soil enzymatic activity with organic farming. Sahaet al. (2008) reported that integrated application of organic and inorganic fertilizer significantly enhanced the invertase activity in soil in a wheat-soya rotation under seasonal conditions.

Invertase (b-D-fructofuranosidase) is a ubiquitous enzyme in soil (Gianfredaet al.2014) that can monitor soil's long term productivity. This enzyme decomposes complex organic compounds into simpler subunits that can assimilated by microorganisms which lead to delayed alteration in microbiological parameters. Invertase activityshared a positive correlation of $r=0.839$ and $r=0.943 @ 0.01$ level of significance with amylolytic bacterial population and amylase activity, respectively in treatment having bio-inoculant application.

Whereas; application of green manure with and without bio-inoculants significantly enhanced correlation coefficient of invertase activity ( $\mathrm{r}=0.985$ and $\mathrm{r}=0.983$ @ $\mathrm{p}=0.01)$ with amylase enzyme, respectively. The present results were supported by Adriano et al. (2012)that all enzymatic activities increased with application of organic manures.

The addition of organic material to the soil in corn crops favoured invertase, cellulase (the enzyme that decomposes cellulose, the most abundant polysaccharide in plant cellular walls), urease and phosphatase activity. Similar results were reported by Kandeleret al. (1999) that invertase activity is higher in soils amended with organic matter. Martens et al. (1992) noted an increase in invertase activity in soils with straw residue. Yang et 
al. (2008) showed that the activity of this enzyme increased when organic manure was added to cucumber plants (Cucumissativus L.).

Cellulase enzyme hydrolysed the $\alpha-1-4$ glycosidic linkage of long polysaccharide of glucose. Cellulase activity showed significant positive correlation with cellulose utilizing bacterial population in all treatments indicated that some specific group of bacteria were able to secrete the cellulase enzyme in soil.

Application of bioinoculant (alone or with green manure) significantly enhanced the correlation coefficients which reflected that application of bioinoculant directly enhanced the number of cellulose utilizing. Cellulase activity has significant positive correlation with amylolytic bacterial population in all treatments. Cellulase enzyme has significant positive correlation with all enzyme activities in treatment $\mathrm{T} 3$ and $\mathrm{T} 4$ as compared to other treatments.

This results indicated that organic matter addition increased the nutrient availability in terms of improve enzyme secretion by healthy soil microbiota. Kautzet al. (2004) reported that cellulase activity in the soil increased significantly with the incorporation of straw and green compost. Deboszet al. (1999) found that carbon related enzyme activity in soils fertilized with bio-solids, straw and green compost was higher in comparison to the activity of these enzymes in soils that only received nitrogen fertilization. Kauret al. (2018) also reported that application of green manure resulted in significant positive correlation between microbial population and soil enzymatic activity. Chang et al. (2007) concluded that the increase of enzymatic activity in soils treated with organic residues has been attributed to a combined effect of (i) a higher degree of enzyme stabilization with the formation of organo-mineral complexes as a result of the increase in humus content and (ii) an increase in the microbial biomass due to the increase of the organic carbon content.

The combined application of organic and mineral fertilizers can increase enzymatic soil activity due to the easily-available, enriched nutrients from mineral fertilization and the high levels of organic material and biological activity promoted by the addition of organic fertilizers.

The alteration in land use management practices may results into physical and chemical changes in soil, so there is a direct expression on microbial biomass and soil enzyme activities.

In our study application of organic matter addition in form of Crotolariajuncea green manure combined with bioinoculant significantly favoured bacterial population in soil and enhanced the correlation of carbon related microbial communities with enzymatic activities. Thus, lead to improved overall health, quality and sustainability of soil ecosystem.

\section{References}

Adriano M de L, Gutiérrez F, Dendooven L, Salvador-Figueroa M.Compost and liquid bioferment on the chemical and biological characteristics of soil cultivated with banana (Musa spp. L.). Journal of Soil Science and Plant Nutrition 2015; 12: 33-43

Balota EL and Chaves RJCD. Enzymatic activity and mineralization of carbon and nitrogen in soil cultivated with coffee and green manures. The RevistaBrasileira de Ciência do Solo 2010; 34:1573-1583.

Bandick AK and Dick RP. Field management effects on soil enzyme activities. Soil Biology and Biochemistry 1999; 
31:1471-1479.

Boruta BB, Paluszak Z. Occurrence of amylolytic microorganisms in soil depending on the type of cultivation. $\mathbf{J}$ Ecohydrologyand hydrobiology 2006; 6:175-80.

Chang EH, Chung RS, Tsai YH.Effect of different application rates of organic fertilizer on soil enzyme activity and microbial population. Soil Science and Plant Nutrition 2007; 53: 132-140.

Cole MA. Lead inhibition of enzyme synthesis in soil. Applied Environmental Microbiology 1997; 33:262-68.

de Vries FT, Hofflanda E, Eekerenc NV,Brussaarda L, Bloemb L. Fungal/bacterial ratios in grasslands with contrastingnitrogen management Soil Biology and Biochemistry 2006; 38: 2092-2103.

Debosz K, Rasmussen PH, Pedersen AR. Temporal variations in microbial biomass $\mathrm{C}$ and cellulolytic enzyme activity in arable soils: Effects of organic matter input. Applied Soil Ecology 1999; 13: 209-218.

Deng SP and Tabatabai MA.Cellulase activity in soils. Soil Biology and Biochemistry 1994; 26:1347-54.

Dick RP. Soil enzyme activities as indicators of soil quality. In: Doran JW, Coleman DC, Bezdicek DF and Stewart BA Eds. Defining soil quality for a sustainable environment. Madison, Soil Science Society of America, 1994. p.107-124.

Dick RP. Soil enzyme activities as integrative indicators of soil health. In: Pankhurst CE, Doube BM and Gupta VVSR eds. Biological indicators of soil health. Wallingford, CAB International, 1997. p.121-156.

Gianfreda L, Sannino F, Violante A. Pesticide effect on the activity of free, immobilized and soil invertase. Soil Biology and Biochemistry 1995; 27:
$1201-1208$.

Kandeler E, Stemmer M, Klimanek EM. Response of soil microbial biomass, urease and xylanase within particle size fractions to long-term soil management. Soil Biology and Biochemistry 1999; 31: 261-273

Kaur J, Gosal SK, Walia SS. Correlation of microbial population with enzymatic activities and nutrient levels of soil during paddy growth. Current Journal of Applied Science and Technology 2018; 29:1-9.

Kautz T, Wirth S, Ellmer F. Microbial activity in a sandy arable soil is governed by the fertilization regime. European Journal of Soil Biology 2004; 40: 87-94.

Malik AA, Chowdhury S, Schlager V, Oliver A, Puissant J, Vazquez PGM, Jehmlich $\mathrm{N}$, von Bergen $\mathrm{M}$, Griffiths RI and Gleixner G. Soil fungal:bacterial ratios are linked to altered carbon cycling. Frontier in Microbiology 2016; 7(1247): $1-11$.

Martens DA, Johanson JB, FrankenbergerJr WT. Production and persistence of soil enzymes with repeated addition of organic residues. Soil Science 1992; 153(1): 53-61.

Myoeków W, Stachyra A, Ziêba S, Masiak D. Biological activity of soil as an index its fertility. RoczGlebozn 1996; 47: 89-99.

Olsen RA, Bakken LR. Viability of soil bacteria: optimization of plate-counting technique and comparison between total counts and plate counts within different size groups. Microbial Ecology 1987; 13(1):59-74.

Perucci P, Bonciarelli U, Santiloschi R, Bianchi AA.Effect rotation, nitrogen fertilization and management of crop residues on some chemical, microbiological and biochemical properties of soil.Biology and Fertility of Soils 1997; 24:311-16. 
Saha S, Prakash V, Kundu S, Kumar N, Mina BL. Soil enzymatic activity as affected by long term application of farm yard manure and mineral fertilizer under a rainfed soybean-wheat system in N-W Himalaya. European Journal of Soil Biology 2008; 44: 309-315.

Strickland MS and Rousk J. Considering fungal: bacterial dominance in soilsmethods, controls, and ecosystem implications. Soil Biology and Biochemistry 2010; 42: 1385-1395.

Tabatabai MA. Enzymes. In: Weaver RW, Augle S, Bottomly PJ, Bezdicek D, Smith S, Tabatabai A and Wollum A. Eds Methods of soil analysis-Microbial and biochemical properties. Madison,
Soil Science Society of America, 1994. Part 2.p.775-833.

$\mathrm{Tu} \mathrm{CM}$. Influence of pesticides on activities of invertase, amylase and levels of adenosine triphosphate in organic soil. Chemosphere 1982; 2:909-14.

Yang L, Li T, Li F, Lemcoff JH, Cohen S. Fertilization regulates soil enzymatic activity and fertility dynamics in a cucumber field. ScientiaHorticulturae 2008; 116: 21-26.

Zhang CE, Liang YL. Effect of different amounts of nitrogen and phosphorus fertilizers applied on soil microbial biomass during corn growth periods. Chinese Journal of Ecology and Agriculture 2001;9: 72-74.

\section{How to cite this article:}

Jaspreet Kaur, S. K. Gosal, S. S. Walia, Jupinder Kaur and Neha Khipla. 2020. Interaction of Different Carbon Related Microbial Activities as Influenced by Green Manure and Bio inoculants in Kharif Maize Crop. Int.J.Curr.Microbiol.App.Sci. 9(02): 286-294. doi: https://doi.org/10.20546/ijcmas.2020.902.036 